\title{
AN SPEECH ACT USED BY ANNA AS THE SECOND CHARACTERS IN " FROZEN" MOVIE SCRIPT
}

\author{
Nadia Sofia Fitri Dahlia ${ }^{1}$, Neng Lina ${ }^{2}$, Rasi Yugafiati ${ }^{3}$ \\ ${ }^{1}$ IKIP Siliwangi \\ ${ }^{2}$ IKIP Siliwangi \\ ${ }^{3}$ IKIP Siliwangi \\ ${ }^{1}$ nadiasofia303@gmail.com, ${ }^{2}$ nenglina1994@gmail.com, ${ }^{3}$ tanya.rasiyugafiati@gmail.com
}

\begin{abstract}
This research entitled An Analysis Speech Act Used By Anna As The One of Characters in "Frozen" Movie Script, in this analysis the writers to find out the utterances that appear and the influence for the hearer aster the utterances is stated. Each speech showing three parts of speech acts, namely locutionary, illocutionary, and perlocutionary. However, this study only focuses on the discussion of illocutionary acts because basically the aim of the research is to find out what illocutionary acts used by Anna as one of the characters in the frozen movie so that the sense of a speech can be understood well in certain social interaction. The film of Frozen was chosen as the source of the data in this research because of the many illocutionary acts of speech spoken by Anna. The data was collected from the "Frozen" movie script . Based on the result of the study, the data found there are five kinds of illocutionary acts in the script, namely; 102 representatives forces, 32 directives forces, 11 commisive forces, 41 expressives forces, and 1 declarative force.
\end{abstract}

Keywords: Film, Speech Act, Illocutionary Act

\section{INTRODUCTION}

Language is a tool for human being to exchange information with other people throughout the world. Without language we cannot communicate, this is suitable with the opinion of language According to Armstrong \& Ferguson (2010), language as a collection of which means creating resources that are crucial to everyday communication and that alter speaker not solely swhich to convey information to every alternative however additionally to keep up social relationships within the sense of each dealing and interaction. To make easier in employing language for communicate, we need two tools such as "The language used for two important means, namely linguistic and pragmatic means. Linguistic tools connect to the accuracy of the form and structure of language, while pragmatics are relate to the compatibility of shapes and structures with the case of the user." The function of language in communication requires two important mediums, namely the linguistic and pragmatic medium. Linguistic media is connecting of accuracy and structure of language, while pragmatic media is connecting to the matter of accuracy and structure of use of context. Pragmatics are among of the important terms in language study. Based on stated by Akinwotu (2013) simply defined pragmatics as the study of language in use. In communication, we need partners or listeners to comprehend and respond to what we are talking about. Pragmatics has many aspects; among of the speech act. Pragmatics refers to meaning construction in specific international context, it also cite to the study of meaning in use or meaning in interaction (Maullany \& Petter, 2010).

Speech act has a role of meaning in sentences for communicating in our daily lives, such as apology, greeting, request, complaint, invitation, compliment, and refusal. Thoyyibah \& Basra (2017) stated that speech act are those of making statement or question, giving commands or 
order, refusing, complimenting, apologizing, and etc. Speech action theory says that actions taken when speech is generate so that can be classified at three different levels. The first is that locutionary actions are equivalent to pronouncing certain sentences with certain meanings and references which are again roughly equivalent to 'meaning' in the traditional meaning. The second is illocutionary actions such as giving information, ordering, warning, doing. The third is locutionary actions reach out by conveying a message like convincing, persuading, releasing, and even, saying, giving or misleading.

From the statement above, the writers will only focus on the kinds of speech acts in the categories of illocutionary actions / strength according to Searle. Speech actions can be found in film dialogues. To analyze the illocutionary aspects, the writers has selected data from the greeting "FROZEN" movie script. This film is very interesting because it contains a lot of dialogues that can be analyzed by the writers, particulary from the illocutionary angle of speech acts. The goal of this study is to identify the illocutionary act in frozen movie script and understand how the meaning of speech acts can be interpreted.

Speech acts or illocutionary acts have classification. Different scholars develop their own taxonomy of speech acts classification (Thoyyibah \& Basra, 2017). Ilocutionary category to clarify the meaning of speech, Searle (1976) proposed that speech acts can be grouped into general categories based on word and world relations. There are five types of basic actions a person can do in speaking through the following types: representation/assertive, direction, commission, expressiveness, and declarative.

1. Representative / Assertive are used in argumentative communication actions which need to convey opinion in a solid, briefly and emotional. The grammatical forms of aspiration require implications produced by illocutionary representatives, so that messages or opinion can be expressed and understood. This is include: stating opinion, suggest, informing, explaining, and complain

2. Directives, this second category means the utterance in this category attempt to make the addres perform an action. Directives perform commanding, ordering, requesting, warning, suggesting, inviting, and etc.

3. Commissives category means a speech act that binds the speaker to carry out everything mentioned in the speech. They are promising, threatening and offering.

4. Expressive, this speech act is also called evaluative speech action. Expressive speech acts are speech act that are intended by the speaker so that the speech is interpreted as an evaluation of the things mentioned in the speech. Including speech saying thank you, congratulating, praising, etc.

5. Declaratives, speech act declaration is a speech act intended by the speaker to create a new state and soon.The paradigm cases are: excommunicating, declaration war, firing, christening, and etc.

\section{METHOD}

The method used in this study was descriptive qualitative. In this research the writers analyzed the speech acts based on the data, movie script by Jennifer Lee (2013) in Frozen movie script based on the illocutionary act types by Searle's classification that used by Anna in Frozen movie. Then the writers analyze and interpreted the data that presented the fact systematically, therefore it can be comprehend and concluded easily. In collecting the data, the method used 
was library research. In library research, there is not respondents involved in this study as commonly used in quantitative research. In applying the library research, there were some techniques used to collect the data such as observing the movie, note taking the movie characters' utterances and identifying the illocutionary acts. Firstly, since the data is a movie, thus it was carefully and repeatedly watched. Secondly, together with the first step, the dialogues that are relevant to the topic were noted-down and given several details of the speaker and the scene.

\section{RESULTS AND DISCUSSION}

\section{Results}

The finding shows that five kinds of illocutionary acts are performed by Anna as one of the characters in Frozen movie. They are assertives, directives, commissives, expressives and declaration. Each of the kinds of the illocutionary acts has its own illocutionary forces which presented in table 1:

\begin{tabular}{|c|c|c|c|}
\hline No & $\begin{array}{l}\text { Classification } \\
\text { of } \\
\text { Illocutionary } \\
\text { Acts }\end{array}$ & $\begin{array}{c}\text { Kinds of Illocutionary } \\
\text { Force }\end{array}$ & Example \\
\hline 1. & $\begin{array}{l}\text { Assertives } \\
\text { (102 Forces) }\end{array}$ & $\begin{array}{l}\text { b. Suggesting } \\
\text { c. Informing } \\
\text { d. Explaining } \\
\text { e. Complaining }\end{array}$ & $\begin{array}{l}\text { I've never been better. This is so } \\
\text { nice. I wish it could be like this all } \\
\text { the time. } \\
\text { Wait. Would we live here? } \\
\text { I suddenly see him standing there, a } \\
\text { beautiful stranger tall and fair. } \\
\text { I love you, Olaf. } \\
\text { We used to be best buddies and } \\
\text { now we're not. I wish you would } \\
\text { tell me why. }\end{array}$ \\
\hline 2. & $\begin{array}{l}\text { Directives } \\
\text { (32 Forces) }\end{array}$ & $\begin{array}{l}\text { a. Commanding } \\
\text { b. Directing } \\
\text { d. Requesting } \\
\text { f. Warning }\end{array}$ & $\begin{array}{l}\text { Do the magic ! Do the magic ! } \\
\text { Go ahead, I won't judge } \\
\text { Bring me my horse, please ! } \\
-\end{array}$ \\
\hline 3. & $\begin{array}{l}\text { Commisive } \\
\text { (11 Forces) }\end{array}$ & $\begin{array}{l}\text { a. Promising } \\
\text { b. Offering } \\
\text { c. Threatening }\end{array}$ & $\begin{array}{l}\text { See you in two weeks. } \\
\text { Do you want to build a snowman } \\
\text { - }\end{array}$ \\
\hline 4. & $\begin{array}{l}\text { Expressive } \\
\text { (41 Forces) }\end{array}$ & $\begin{array}{l}\text { a. Stating Surprise } \\
\text { b. Stating Pleasure } \\
\text { c. Thanking } \\
\text { d. Stating Anger } \\
\text { e. Insulting }\end{array}$ & $\begin{array}{l}\text {... the bell .. the corronation.. I have } \\
\text { to go there! } \\
\text { For the first time in the forever, } \\
\text { there'll be magic, there'll be fun. } \\
\text { Thank, goodness. } \\
\text { You won't get away with this } \\
\text { You're not match for Elsa. }\end{array}$ \\
\hline
\end{tabular}


f. Complimenting

g.Stating Anxiety

h. Apologizing

i. Stating Panic

j. Greeting

k.Stating Confusion

5. Declaration

(1 Forces) a. Resigned

b. Baptized

c. Fired

d. Give a name

e. Sentenced

f. Excomunicated
You look beautifuller. I mean not fuller. You don't lokk fuller but more beautiful.

It's agony to wait.

I'm sorry for my fault.

That's horrible

Hi, Kristoff !

\section{Discussion}

After the writers watched and analyzed the data from script that written by Jennifer Lee, the writers found five kinds of illocutionary act in the script that had been analyzed. Based on table: 1 above, the writers will be discussed about the result. The categories of illocutionary act from the movie script as follows: 102 forces of representatives/assertive, 32 forces of directives, 11 forces of commisives, 41 forces of expressives, and 1 force of declarative categories at the "Frozen" movie script. The writers present the utterances of illocutionary act that used by Anna as one of the characters in frozen movie. Then, the writers directly analyze the data as follows: Illocutionary act:

The utterance (I've never been better. This is so nice. I wish it could be like this all the time) included stating of representative/assertive act. Young Anna stated that she felt better than before and wanted the time to continue forever, because in the past she felt alone and when the corronation was held she felt no longer alone again because of many friends and the situation on the corronation time is very happiness for her. According to Searle define that in representative/assertive act there are parts and one of them is a stating opinion which means that the person's statement gives a statement in the form of an opinion that he feels at the time. The utterance (See you in two weeks) included stating of commisive act, in this scene Anna stated that she will meet again with her parents on two weeks later in other words Anna make promising to her parents so they can meet together again. Based on Searle argued in commisive act there are parts and one of them is promising which explains that utterances the person that give a promise to someone.

The utterance (She's named you the official Arendelle Ice Master and Deliverer) included stating of declaration act, in this scene Anna give a name for Krissthof as the official ice master and deliverer because he has master ability in the field. According to Searle stated that in the declaration parts there is give a name this part explain the speaker give a name for someone in his/her utterances.

The utterance ( Do the magic ! Do the magic!) included stating of directive act, in this scene Anna ask to Elsa pulled out the magic for they can play together. From Searle stated that in the directive act there are categories and one of them is commanding that has meaning to make the addresses perform an action. 
The utterance (I'm sorry for my fault.) included stating of ekspresive act, Anna stated that she apologized to Elsa for the mistakes she made. This is supported by Searle that in the ekspressive act have some categories among of are apologizing which has means express a psychological state.

In this research, it can be concluded that in Anna's utterance as one of the characters from Frozen move, we can see that the classification of illocutionary acts from Anna's utterance is at most amount 102 forces. This is because the utterance Anna contains many expressions such as stating opinion, suggesting, informing, explaining and complaining, compared to other classifications of illocutionary acts and at least is declarative acts because Anna's utterances only reveal one of type of declarative, namely given name for someone.

\section{CONCLUSION}

From the analysis about speech act categories of illocutionary act in "Frozen" movie script, the writer would like to draw the conclusion as follows:

Utterances in this script have another intention from the speaker. It is the meaning of illocution acts. According to Searle, there are five categories of illocution force/ acts. There are: representative that point out about in truth, directive try to built receipent perform an action, commisives that commit the speakers to doing something one things within the future, expressive the one that expresses speaker feels about the situation, and declaratives that plan to modification the world.

The writer found that kinds of illocution act in the script that had been analyzed. There are five categories of illocutionary act from the movie script as follows: 102 representatives, 32 directives, 11 commisives, 41 expressives, and 1 declarative categories at the "Frozen" movie script.

\section{ACKNOWLEDGMENTS}

Alhamdulillahirobbilalamin, all praises to Allah SWT and Muhammad who always give true spirit and strength so, this final article entitled "An Analysis Speech Act Used in "Frozen" Movie Script” had successfully been completed.

During completing the journal the writer obtained many helps, suggestions and motivation from many people. In this study involving various parties, without the participation of the parties involved this research will not be achieved. We as the writers will say thank you for:

1. Rasi Yugafiati, M.Pd as a lecturer who has helped in completing this article and always give us support and guide.

2. All participants who have been willing to participate in the completion of this article.

\section{REFERENCES}

Akinwotu, S.A. (2013). A Speech Act Analysis of the Acceptence of Nomination Speeches of Chief Obafemi Awolowo and Chief M.K.O Abiola. English Linguistics Research, 2(1), 43.

Armstrong, E.M. \& Ferguson, A. (2010). Language, meaning, context, and functional communication. Australia: Edith Cowan University Publications.

Decoursey, A.C. (2011). Language Art in Asia: Literature in Drama in English Potonghua and 
Cantonese. Cambridge Scholars.

Lee, J. (2013). Disney Frozen. Retrieved from http://noamkroll.comfrozen-screenplay Maullany \& Petter. (2010). Introducing English Language. New York: Routledge.

Searle, J. R. (1976). A Classification of Illocutionary Acts. Cambridge: Cambridge University Press.

Thoyyibah, L \& Basra, N. (2017). A Speech Act Anlaysis of Teacher Talk in An EFL. 